\title{
NOTES
}

1 Whitman, The Correspondence, ed. Edwin Haviland Miller (New York: New York University Press, 1961), 2:75.

2 Horace Traubel, With Walt Whitman in Camden (New York: Rowman and Littlefield, 1961), 1:216.

3 Traubel, 216, 217.

4 Traubel, 217.

5 Traubel, 216. The " $\mathrm{s}$ " in swimming is capitalized in the manuscript.

6 Traubel, 217.

7 Traubel, 217.

8 The manuscript poem remains in the hands of the present owner to whom I am grateful for the photographic reproduction.

9 See The Gathering of the Forces, ed. Cleveland Rodgers and John Black (New York: G. P. Putnam, 1920).

10 Emory Holloway, "Notes on 'Passage to India' including 'Thou Vast Rondure,"' Typescript, 20 December 1920. Rare Books and Manuscript Division, The New York Public Library, Astor, Lenox and Tilden Foundations.

11 Fredson Bowers, Whitman's Manuscripts, Leaves of Grass (1860), A Parallel Text (University of Chicago Press, 1955), xix, xx.

12 Emory Holloway, Whitman, An Interpretation in Narrative (New York: Alfred A. Knopf, 1926), 5.

\section{TWO CITATIONS: AN EARLY WHITMAN ARTICLE AND AN EARLY REPRINTING OF "DEATH IN THE SCHOOL-ROOM"}

As Scott Giantvalley and all bibliographers know, completeness is virtually impossible: he himself, in the Walt Whitman Quarterly Review, 4 (Summer 1986): 2440, adds 120 items to his massive Walt Whitman, 1838-1939: A Reference Guide(Boston: G. K. Hall, 1981). An additional article is:

Anon. "Our Boston Literary Letter: Whittier, Whitman, Emma Lazarus." The Daily Springfield Republican, 15 January 1889, pp. 2-3.

The author of this unsigned review-essay begins: "The definitive edition of Whittier's works, both verse and prose, in seven volumes, four of which are in verse, has been appealing to me for some weeks to write its eulogy and critique; and now has come as a holiday gift from the good gray poet himself the more pathetic definitive edition, in one volume of Walt Whitman's verse and prose, - his 'Complete Poems and Prose,' 1855-1888, 'Authenticated and Personal Book (handled by W. W.),' in which the stout-hearted, but feeble-bodied, old man says his long farewell to his readers." After a full column and a half comparison of Whittier and Whitman, the reviewer-essayist devotes a long paragraph to Emma Lazarus, in 
whose two volumes she "speaks to her readers collectively and no longer in ejaculations from the magazines." The reviewer concludes that "few of her own sex who wrote verses in English during her life-time surpassed her in the art and gift of poetry, yet her volumes are rather painful than pleasure giving and there rest upon her memory a pathetic mist, like that which surrounds and magnifies the fame of Margaret Fuller." In a letter to Richard Maurice Bucke, dated 17 January 1889, Whitman writes: "have rec'd a Springfield Republican with a long criticism of 'Whittier, Whitman \& Emma Lazarus' evidently by Frank Sanborn - wh' I will send you in a day or two-" (Edwin Haviland Miller, editor, The Correspondence of Walt Whitman [New York: New York University Press, 1969], 4:270).

Walt Whitman's short story, "Death in the School-Room (a Fact)," which was originally published in the Democratic Review, 9 (August 1841), 177-181, is the most often reprinted of his short fiction. As recorded in two of my bibliographies, it appeared in the Long Island Farmer, 10 August 1841; New York Mirror, 21 August 1841; Ladies Garland, September 1841; The Mauch Chunk Courier, 25 October 1841; Brooklyn Daily Eagle, 24 December 1847; and in editions of Whitman, Specimen Days and Collect, Complete Prose Works, and The Early Poems and the Fiction, Collected Writings. Jon Guillot, proprietor of Magnum Opus Rare Books, Charlottesville, Virginia, has now turned up an additional reprinting in the Whitman collection of Robert O. Harris, Jr., of Dallas: Salem Gazette (Salem, Massachusetts), Vol. 55, No. 63, p. 1, 6 August 1841. Its first printing in the Democratic Review is acknowledged. When Whitman was "elated at the success of his sketch," which was widely copied, he knew what he was talking about. 